\title{
ANALYSING THE ATTRIBUTES OF ECOLOGICAL EVALUATION ON LOCAL AND REGIONAL LEVELS VIA WILLINGNESS TO PAY (WTP) - A HUNGARIAN CASE STUDY
}

\author{
FOGARASSY, Cs. ${ }^{*}-$ KERPELY, K. - HORVATH, B. - BAKOS BOROCZ, M. \\ Szent István University, Faculty of Economics and Social Sciences, Institute of Regional \\ Economics and Rural Development, Climate Change Economics Research Centre Pater Karoly \\ st. 1, Gödöllö, H-2100, Hungary \\ (phone: +36-28-522-000 ext.:2060; fax: +36-28-522-925) \\ *Corresponding author \\ e-mail: fogarassy.csaba@gtk.szie.hu \\ (Received $2^{\text {nd }}$ Mar 2016; accepted $25^{\text {th }}$ Apr 2016)
}

\begin{abstract}
The need for integrating natural resources into the development and decision-making processes of various sectors on a political level is becoming more and more apparent in the European Union. The number of ecological evaluation projects is on the rise, the areas of usage include anywhere from local, through national, to global levels. This study's results offer answers to: how local, and regional (national) Willingness to Pay (WTP for short), in other words, social interpretation of natural resources differ through Hungary; and how income, or personal connection becomes a defining factor for forming preferences regarding certain values. Local and regional WTP values were compared to the social-related costs of both a local, and a national ecological evaluation project. The analyses showed that different WTP evaluations yielded very different results, and that actual rehabilitation costs can be defined via different characteristics for various projects.
\end{abstract}

Keywords: ecological evaluation, willingness to pay, ecosystem service, natural resources, water preservation

Abbreviations:

CVM - Contingent Valuation Method

HCSO - Hungarian Central Statistical Office

WTP - Willingness to Pay

\section{Introduction}

Our research aims to economically evaluate a certain domestic sample area via methods applicable to converting natural resource capital to monetary values. The focus of our research is the revitalisation project of the Szabadság Island side branch of the Danube, in Mohács town. The goal of the research is to obtain information about the more widely interpreted results and social effects of the rehabilitation conducted mainly for environment protection reasons. The project from the very beginning was expected to have the surplus advantages of various social-economic benefits apart from the environmental perspective. This research aims to capture these benefits figures, two years after the project has concluded, by which the state of the environment becomes interpretable and analysable in economic terms. We also aim to examine if the locals' efforts to sustain the rehabilitated environment - without state intervention - may be successful in the next ten years.

The definition of natural capital is used differently by authors with varied approaches, yet often these are close to each other, and overlap. The source of the 
definition is said to be the usage of the basic term of economics, "capital", for nature (Boros, 2004; Brand, 2009; Teeb Foundations, 2010). Many argue that the definition was intended as a metaphor in the beginning, which could define the finiteness of physical and biological resources on Earth, also interpretable by economics (MA, 2005; Norgaard, 2010). However, the economics analogy holds true if we define natural capital as a stock which can create, and supply a constant flow of valuable products or services for society (Costanza, Daly, 1992; Bateman et al., 2006). A real economic valuation builds on the biophysical understanding and goals to measure people's preferences for the benefits from ecosystem processes. These advantages or benefits may accrue to different categories of population over different geographical and time scales (Pavan, 2008).

We may consider the evaluation a process of information compression, which can embrace the different attributes of any given object or definition into a collective, and by extension, comparative attribute, the value (Vatn and Bromley, 1994; Van Zanten et al., 2014). Economics usually handles this one-dimension value measurement indicator in the form of the price, defined by the market, and in money, which is determined during market transactions, along the preferences of market actors. Living nature, and its ecosystem services are usually public goods and quasi-public goods however, which don't have a market. This lack of markets - not including some well-defined capital elements - makes it difficult to define the natural capital's value (Turner et al., 1994; Koopman et al., 2015). The most significant challenge of today is to economically evaluate the ever-decreasing bio-diversity (Nijkamp et al., 2008). Evaluating the results of already realised projects - together with actual budget numbers - should be integrated into the protocol of WTP methodologies.

\section{Materials and Methods}

\section{WTP analysis with contingent valuation}

To translate into figures the effects changes in natural resources have on human welfare, the most used stated preference method is the Contingent Valuation Method (CVM for short). This method can translate both the usage-related, both the non-usagerelated elements of total economic value to numbers (Pearce and Moran, 1994; Marjainé, 2005). An important benefit is that the possible errors and inconsistencies were unearthed during the three-decade development of the methodology, which can be accounted for, and corrected by implementing proper techniques. The NOAA Committee, organised in the USA evaluated the up-to-date CVM practice in 1993, and found the contingent valuation to be an applicable ecological evaluation method (Arrow et al., 1993). Their recommendations have since integrated into the methodology, to correct known hardships and setbacks it imposed.

Our survey was conducted on Mohács town sample and on a national one. So it required two different questionnaires on these levels. The opinions of Mohács town inhabitants were collected via face-to-face questionnaires in autumn 2014. The sampling was conducted on public areas of Mohács town (total population of the town was 19,000 heads in 2014), by asking easy to approach participants. The national questionnaire was strictly online. The national level questionnaire was filled out by 96 people in autumn 2014, everyone for their own will. Naturally, this sample number on its own isn't enough to draw general conclusions for the entire country's inhabitants, but this part of the research never intended to create a strictly representative sample. 
We wanted to work with a sample which may help us in understanding the opinions of people living farther from the area in question. Cross-referencing our data with that of the Hungarian Central Statistical Office, we came to understand that the sample is representative for the entire population of Hungary in terms of gender ratio. As for the other indicators in the sample, the younger generation, those who underwent higher education, active workers, inhabitants of the capital, and those living in larger households are over-represented. Based on the HCSO data, the net average income per capita is about 1.5 times higher than the national average.

The local and national questionnaires were identical, apart from minimal changes needed due to different levels of knowledge on the area. A difference was that possible answers were pre-determined, instead of allowing free wording of their answers.

We were interested in the analysis of locals' and non-locals' willingness to pay basically because international case studies came up with significant differences between the two values before. This is natural, however, since locals consider environment protection projects more important, meaning they may possibly offer higher amounts for them, regardless of income (Boddington, 1993; Bateman et al., 2004). Meanwhile, the decision to offer money of those living farther from the location showed connection with the level of income.

\section{Questionnaire}

Questionnaires are useful in cases when we need data which can be statistically processed, and generalised. As for WTP analyses, this is a mandatory requirement, as we're not exclusively interested in indicators, which we can request from statistical databases (Koetse and Brouwer, 2015). The reason is that the basis of willingness to pay analyses is the personal questioning of people, during which we offer them an opportunity to estimate the value of nature for them in monetary terms. Therefore, even though WTP analyses are not really widespread in the scientific fields due to their inherent complications, they become the sole method of measuring the opinions of inhabitants in monetary units. It helps with decreasing the top-down nature of state interventions in long-term, and including society in decision-making gets a higher possibility (Van den Bergh and Botzen, 2015). Using questionnaires, we collected the opinions of the inhabitants of Mohács town in autumn 2014, as part of a contingent valuation analysis. Parallel to this, we conducted a national online questionnaire data collection, with the same content. Therefore, local and national WTP data became comparable, and possible to evaluate. In order to understand the economic value of WTP data as well, we conducted analyses on similar projects in different areas of the country as a reference check, and compared our calculated WTP value with the actual cost of the submitted rehabilitation project.

\section{Results}

\section{Analysing the willingness to pay in Mohács town}

When the local questionnaire was concluded, the sample consisted of 51 people. The primary results can be seen in Table 1 . We can see that only about half, 26 people have a positive willingness to pay, who would offer 17,45 EUR on average for sustaining the local ecology. 
Table 1. Non-cleaned results of Willingness to Pay in Mohács town $(n=51)$

\begin{tabular}{|l|c|}
\hline Indicator & WTP \\
\hline Frequency, WTP $>0$ & $26(51 \%)$ \\
\hline Average WTP & 17,45 EUR \\
\hline Deviation & 49,5 EUR \\
\hline Median & 3,3 EUR \\
\hline Minimum (WTP $>0)$ & 3,3 EUR \\
\hline Maximum & 333,3 EUR \\
\hline Modus (WTP $>0)$ & 6,6 EUR, 16,6 EUR \\
\hline
\end{tabular}

Naturally, we were also interested in what the negative and positive nature of willingness to pay are in connection with, therefore, we also asked our participants to state their reasons. $65 \%$ of those who were willing to contribute with money to the local environment protection goals chose to reason with 'conservation'. And in case of negative willingness to pay, the most frequent answer was the low income of the household (28\%). Furthermore, 20\% was a significant number, whereby people answered that public funds should cover such projects.

However, based on processed literature, we could see how primary results may contain contradictions and extreme values in many cases. The former would list cases such as someone begins the questionnaire by writing that they consider contributing to the area's nature conservation - meaning they consider it valuable - but by reaching monetary contribution, their answer given is 0 . To reach valid values, we cleaned our sample of such cases, and also excluded the highest value, the 333,3 EUR contribution, after which we worked with a sample number of 44. Table 2 shows the actual WTP value.

Table 2. Valid WTP values in Mohács town

\begin{tabular}{|c|c|c|c|}
\hline & Average WTP & Median & Median; WTP for >0 \\
\hline $\begin{array}{c}\text { Total number of answers } \\
(\mathrm{n}=51)\end{array}$ & 17,45 EUR & 3,3 EUR & $26(51 \%)$ \\
\hline $\begin{array}{c}\text { Cleaned of extremities } \\
(\mathrm{n}=44)\end{array}$ & 12,65 EUR & 6,6 EUR & $25(57 \%)$ \\
\hline $\begin{array}{c}\text { Ratio of Total and } \\
\text { Cleaned }\end{array}$ & $72 \%$ & $200 \%$ & $112 \%$ \\
\hline
\end{tabular}

Another instance of literature highlights the phenomenon of the so-called "embedding effect". This means that though we analysed the opinions related to a given project (Szabadság Island), people are prone to generally interpret environment protection goals - or the given geographical area - thereby giving a different value in terms of their willingness to pay. This is why we need filter questions, by which we can refine the stated values by narrowing them down to the project and its geographical location. Table 3 illustrates the valid WTP values, and their relation to the previously introduced base WTP values. 
Table 3. "Valid" WTP values cleaned of extremities, and the "embedding effect" in Mohács town $(n=44)$

\begin{tabular}{|c|c|c|c|}
\hline & Base WTP & Valid WTP & $\begin{array}{c}\text { Ratio of Valid and } \\
\text { Base WTP values }\end{array}$ \\
\hline Frequency, WTP>0 & $25(57 \%)$ & $18(41 \%)$ & $72 \%$ \\
\hline Avg. WTP & 12,65 EUR & 7,42 EUR & $72 \%$ \\
\hline Deviation & 21,5 EUR & 18,93 EUR & $88 \%$ \\
\hline Median & 6,6 EUR & 0 EUR & - \\
\hline Minimum $($ WTP>0) & 3,3 EUR & 3,3 EUR & $100 \%$ \\
\hline Maximum & 120 EUR & 120 EUR & $100 \%$ \\
\hline Modus $($ WTP $>0)$ & 6,6 EUR, 16,6 EUR & 16,6 EUR & - \\
\hline
\end{tabular}

The chart clearly shows that in the end, merely $41 \%$ of our valid sample number was willing to offer money to support the side branch we analysed, while the others would offer their contributions for more general environment protection goals, and other areas of the Danube. The next most important indicator - being the average amount of contributions - also changed, by $28 \%$, which means a statistically significant value. This means that the primary data has to be cleaned, since the final results are quite different. Therefore, we also conducted the cleaning of data we gathered from the national level analyses.

\section{Estimation of the national willingness to pay}

The focus of the national level was also to economically evaluate the Szabadság Island project of Mohács town in order to determine how the local and global interpretation of an environment protection project differ from each other. Furthermore, the two samples' different values may be important for us, since we should select indicators which cause these differences. The results generated from out 96 sample number obviously can not be considered as a general conclusion for the entirety of Hungary, we were merely interested in the opinions of those living farther from the project area from an orientation perspective. Following the construction of the local evaluation, we began with absolute data seen in Table 4 .

Table 4. Non-cleaned results of Willingness to Pay in the national sample ( $n=96)$

\begin{tabular}{|l|c|}
\hline Indicator & WTP \\
\hline Frequency, WTP $>0$ & $35(36 \%)$ \\
\hline Avg. WTP & 6,52 EUR \\
\hline Deviation & 14,5 EUR \\
\hline Median & 0 EUR \\
\hline Minimum (WTP $>0)$ & 3,3 EUR \\
\hline Maximum & 100 EUR \\
\hline Modus (WTP $>0)$ & 16,6 EUR \\
\hline
\end{tabular}


The difference is quite significant, since of the non-resident we asked, only $36 \%$ have a positive willingness to pay, and the value of WTP is significantly lower as well. The reason behind the positive values results from a simple intention to conserve (74\%), similarly to how it was in the local sample. However, $15 \%$ of the previous participants said that they are active users of the area, which obviously does not surface in this sample. Those who would not aid the cause of the side branch due to problematic income are again, similar in number (23\%). However, those who said that these projects should be paid for by public funds were more in this sample (36\%). This is another difference which may be related to geographical reasons, since in case of projects which they are not directly involved in, residents tend to reason that the state should have a bigger role.

We continued by filtering our sample with our previously used method for the valid WTP values (Table 5), during which the sample was reduced by 18 . However, this time, the values did not really change that much.

Table 5. Valid WTP values in the national sample

\begin{tabular}{|c|c|c|c|}
\hline & Avg. WTP & Median & $\begin{array}{c}\text { WTP for }>\mathbf{0} \\
\text { frequency }\end{array}$ \\
\hline $\begin{array}{c}\text { Total number of answers } \\
(\mathrm{n}=96)\end{array}$ & 6,52 EUR & 0 EUR & $35(36 \%)$ \\
\hline $\begin{array}{c}\text { Cleaned of extremities } \\
(\mathrm{n}=77)\end{array}$ & 6,84 EUR & 0 EUR & $34(44 \%)$ \\
\hline $\begin{array}{c}\text { Ratio of Total and } \\
\text { Cleaned }\end{array}$ & $105 \%$ & - & $122 \%$ \\
\hline
\end{tabular}

However, filtering the embedding effect created a much higher turbulence in the results, since we can see that the valid WTP value became less than half of the original. Most of the participants who were willing to pay up to this point clearly stated that their contribution is meant strictly for general environment protection goals, and merely 20 people said that they would finance the Mohács town project explicitly (Table 6).

Table 6. "Valid" WTP values cleaned of "first" values, and the "embedding effect" in the national sample $(n=77)$

\begin{tabular}{|c|r|r|c|}
\hline & Base WTP & Valid WTP & $\begin{array}{c}\text { Ratio of Valid and } \\
\text { Base WTP values }\end{array}$ \\
\hline Frequency, WTP>0 & $34(44 \%)$ & $20(26 \%)$ & $59 \%$ \\
\hline Avg. WTP & 6,84 EUR & 2,84 EUR & $42 \%$ \\
\hline Deviation & 11,74 EUR & 6,73 EUR & $57 \%$ \\
\hline Median & 0 EUR & 0 EUR & - \\
\hline Minimum (WTP>0) & 3,3 EUR & 1,66 EUR & $50 \%$ \\
\hline Maximum & 66,6 EUR & 33,3 EUR & $50 \%$ \\
\hline Modus (WTP>0) & 16,6 EUR & 16,6 EUR & - \\
\hline
\end{tabular}

Therefore, the conclusion from the data collected during via the questionnaire clearly shows how people think about the same environment protection initiative locally and 
non-locally, after which we will look at the connections behind their answers. This is required because the value and geographical spread of the WTP value can not offer sufficient interpretative strength in and of itself, despite our ability to draw general conclusions. This is due to the possible importance of some qualitative indicators like knowledge of the area for the national sample, or the usage of the area for the local sample. Finally, one of the defining values of such an analysis - most notably in Central and Eastern Europe - is the state of income in general, and analysing contributions in relation to it. Therefore, we have to continue by finding the indicators, that proved to have a significant connection related to the contribution offers.

\section{Connections between willingness to pay, and independent variables}

During our analysis, we searched for connections between willingness to pay, and descriptive variables. We evaluated demographic, and cognitive- and attitude attributes, and cross-referenced them with the resulting WTP values. In the following part, we will introduce the matches where we found significant connections. Out of the independent variables, we used the answers to sex, age, has children and people in the household as they were in the questionnaire's answers. Other variables were derived from the answers we got for the questionnaire.

To understand connections between the frequency of positive willingness to pay, and nominal variables, we used a cross-tabulation, where the strength of the correlation was measured using Cramer's V. To evaluate individual correlations between nominal variables and the WTP sum, we used the Eta-statistics. The correlation between the interval scales and the WTP values, we used correlation calculations, and used linear regression for the income per capita in the end. Tables 7 and 8 illustrate the results of the statistical analysis. These charts only hold the variables where at least weak correlation was found, and significant values were labelled with a *.

Table 7. Correlation between Willingness to Pay, and relevant variables for the Mohács town sample

\begin{tabular}{|c|c|c|c|c|c|}
\hline \multirow{2}{*}{\multicolumn{2}{|c|}{$\begin{array}{l}\text { Mohács town sample } \\
\qquad(n=44)\end{array}$}} & \multicolumn{2}{|c|}{ Base WTP } & \multicolumn{2}{|c|}{ Valid WTP } \\
\hline & & \multirow{2}{*}{\begin{tabular}{|c|}
$\begin{array}{c}\text { Frequency } \\
\text { (Cramer's V) }\end{array}$ \\
- \\
\end{tabular}} & \multirow{2}{*}{$\begin{array}{c}\text { Sum (Eta / } \\
\text { correlation } \\
\text { coefficient) }\end{array}$} & \multirow{2}{*}{$\begin{array}{c}\begin{array}{c}\text { Frequency } \\
(\text { Cramer's V) }\end{array} \\
- \\
\end{array}$} & \multirow{2}{*}{$\begin{array}{c}\text { Sum (Eta / } \\
\text { correlation } \\
\text { coefficient) }\end{array}$} \\
\hline \multirow{4}{*}{ 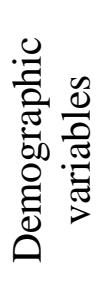 } & Age & & & & \\
\hline & $\operatorname{Sex}(M=1, F=2)$ & $-0,315^{* *}$ & $-0,318 *$ & $-0,289 *$ & $-0,284$ \\
\hline & Size of household & - & $-0,216$ & - & $-0,155$ \\
\hline & $\begin{array}{c}\text { Active earner in } \\
\text { household }\end{array}$ & 0,188 & 0,164 & $0,331 * *$ & 0,158 \\
\hline \multirow{2}{*}{ 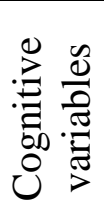 } & $\begin{array}{l}\text { Direct usage } \\
\text { important }\end{array}$ & $0,435^{*}$ & 0,188 & 0,221 & 0,234 \\
\hline & $\begin{array}{l}\text { Had prior } \\
\text { knowledge }\end{array}$ & 0,229 & 0,175 & $0,370 * *$ & $0,267 *$ \\
\hline
\end{tabular}

$* * \mathrm{p}<0,05$, and $* \mathrm{p}<0,1$ 


$$
-136-
$$

Table 8. Correlation between Willingness to Pay, and relevant variables for the national sample

\begin{tabular}{|c|c|c|c|c|c|}
\hline \multirow{2}{*}{\multicolumn{2}{|c|}{ National sample $(n=77)$}} & \multicolumn{2}{|c|}{ Base WTP } & \multicolumn{2}{|c|}{ Valid WTP } \\
\hline & & \multirow{2}{*}{$\begin{array}{c}\begin{array}{c}\text { Frequency } \\
\text { (Cramer's V) }\end{array} \\
0,107\end{array}$} & \multirow{2}{*}{$\begin{array}{c}\begin{array}{c}\text { Sum (Eta / } \\
\text { correlation } \\
\text { coefficient) }\end{array} \\
0,153 * *\end{array}$} & \multirow{2}{*}{$\begin{array}{c}\begin{array}{c}\text { Frequency } \\
\text { (Cramer's V) }\end{array} \\
0,142\end{array}$} & \multirow{2}{*}{$\begin{array}{c}\begin{array}{c}\text { Frequency } \\
(\text { Cramer's V) }\end{array} \\
0,152 * *\end{array}$} \\
\hline : & $\begin{array}{l}\text { Has higher } \\
\text { education }\end{array}$ & & & & \\
\hline$\stackrel{\infty}{0} \cdot \frac{\pi}{3}$ & Size of household & - & $-0,302 * *$ & - & $-0,251 * *$ \\
\hline 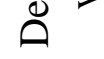 & Has children & $-0,273 * *$ & $-0,245^{* *}$ & $-0,304 * *$ & $-0,268 * *$ \\
\hline \multirow{3}{*}{ 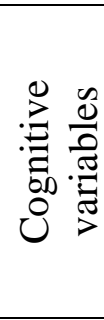 } & $\begin{array}{c}\text { Positive attitude to } \\
\text { environment }\end{array}$ & $0,190 *$ & 0,200 & 0,019 & 0,062 \\
\hline & $\begin{array}{c}\text { Visited Danube- } \\
\text { Drava National Park }\end{array}$ & $0,242 * *$ & $0,283 * *$ & 0,094 & $0,190 *$ \\
\hline & $\begin{array}{l}\text { Had prior } \\
\text { knowledge }\end{array}$ & $0,246 * *$ & 0,370 & 0,153 & 0,238 \\
\hline \multirow{2}{*}{ 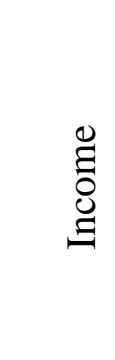 } & $\begin{array}{c}\text { Income of } \\
\text { household by } \\
1 \\
\text { category }\end{array}$ & 0,262 & 0,262 & 0,227 & 0,123 \\
\hline & $\begin{array}{l}\text { Income/capita } \\
\text { regression } \\
\text { coefficient }\end{array}$ & - & $0,012 * *$ & - & $0,006^{*}$ \\
\hline
\end{tabular}

${ }^{1}$ Analysed with exclusion of Don't know / No data answers for income, $\mathrm{n}=66$

We can see that the indicators which effect the results are different for the two cases. The demographic and cognitive variables are different due to the different geographical areas. Since the amount of usage may be important locally, meanwhile, even knowledge on the area may prove lacking nationally. Also, it is not surprising that the income indicators are only present in the national sample, since it is natural that while those living far away from the project will only offer contributions based on their income, locals might find it important enough to disregard that to certain levels. Since this indicator only proved important in case of the national analysis for determining the WTP value, it shall be the first one to be evaluated.

\section{Income and willingness to pay}

The question related to income had an $85 \%$ share for the national level online questionnaire. Both questionnaires' results showed that those who gave a positive offer, the average income of the household, and the average income per capita were higher, but only the national sample yielded a significant difference. In the case of average income per capita, the national questionnaire had a difference of $30 \%$, both from the perspective of the basic, and the valid WTP. 
In the selection by income categories, the frequency of positive offers for the national sample followed the increase in income (but not significantly). However, in Mohács town, income did not influence the frequency of the positive offers. The national sample showed a weak, but significant positive correlation between income per capita, and amount offered as contribution, both in the base WTP, and the valid WTP. The linear regression coefficient was 0,012 for the base WTP, while it was 0,006 for the valid WTP, meaning a 3,3 EUR increase in income yields a 0,02 EUR increase in contribution.

However, the descriptive strength of the indicator is low, as the values of the $\mathrm{R}^{2}$ were 0,082 for the base WTP, and 0,051 for the valid WTP respectively. Figure 1 shows the dot graph and the linear graph.

The lower than expected effect of the income may be explained by how people would spend only a small part of the household's total annual income for this purpose. The national sample's value was $0.02 \%$, while the Mohács town sample's was 0.09 .

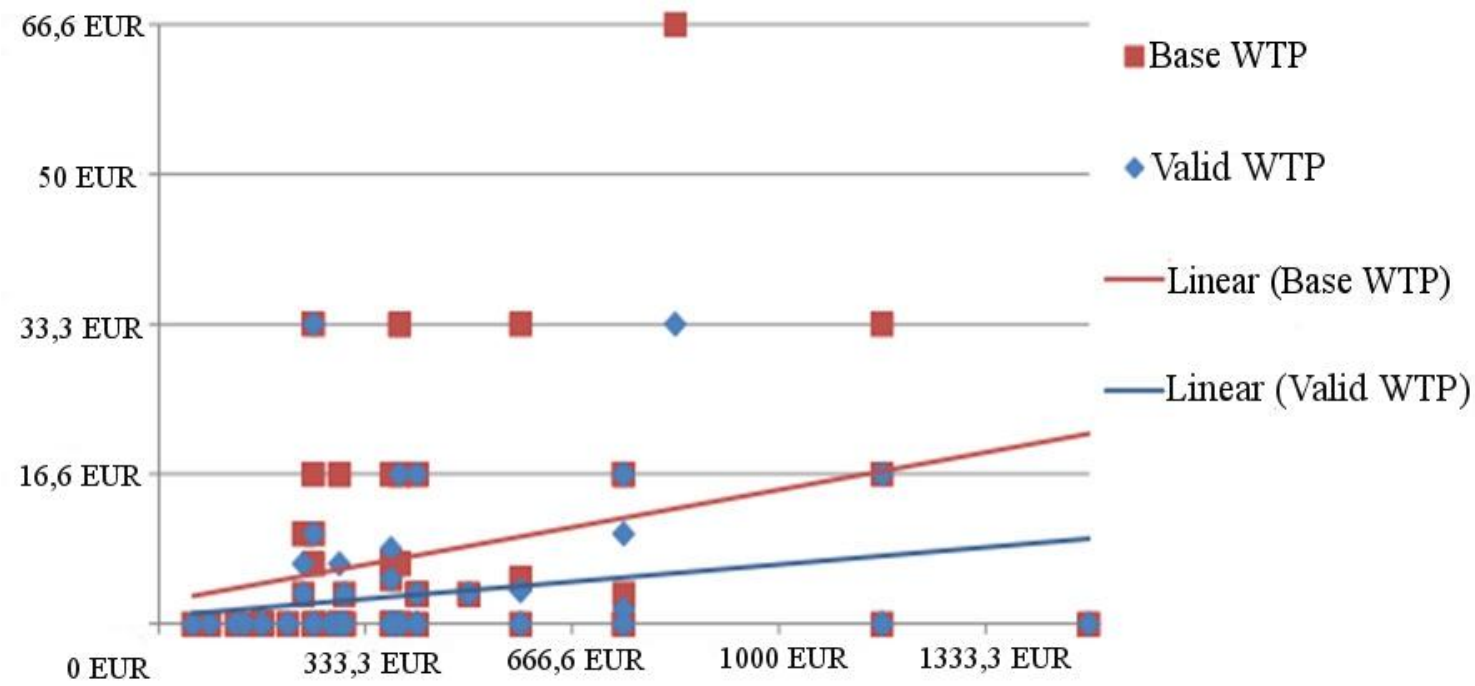

Figure 1. Income per capita and WTP in the national sample $(n=66)$

In Mohács town, neither the income per capita, nor the total income shows correlation to the WTP. However, out of all the indicators related to the monetary welfare of the household, the economic activity (active earner in household) had a significant correlation with the frequency of positive offers. Two-thirds of the participants living in an economically active household made positive offers, while the same could be said about $33 \%$ of the economically inactive households' members. The first WTP offer of active earners was more than 3,5 times more than that of households with no active earner (Figure 2). In the case of valid WTP, in households where no active earner lived, the contribution offers were always zero. The latter can also be said for the national sample. 
Outer circle: economically active households Inner circle: economically inactive households

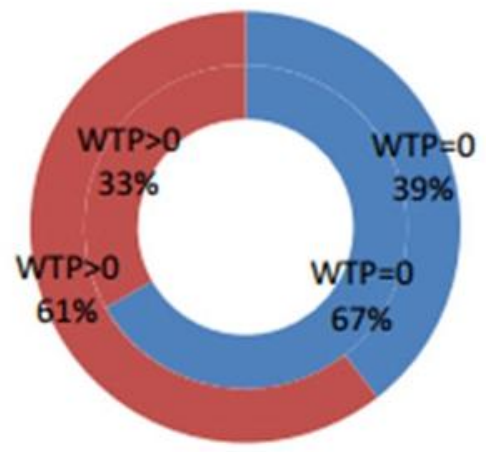

$16,6 \mathrm{EUR}-$

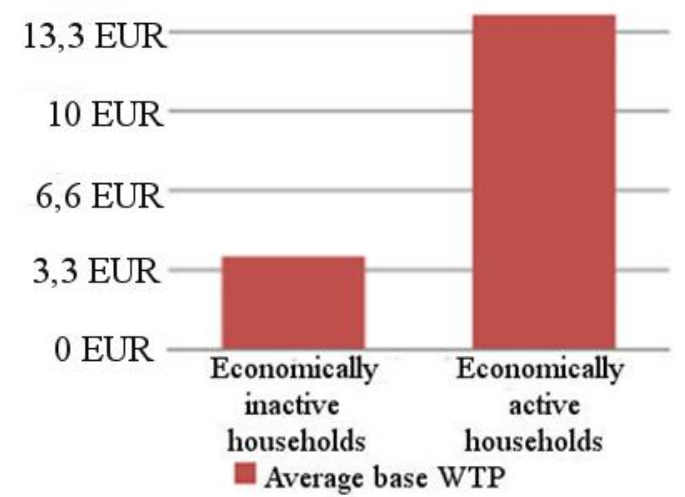

Figure 2. Base WTP and economic activity in Mohács town (n=44)

\section{Correlation between demographic indicators and WTP}

The Mohács town sample showed significant correlation between the WTP value, and the sex of the answering participant. Men had double the frequency of positive contribution offers compared to women, while the average of the WTP sum was four times as much. This may be explained by the significant difference in prior knowledge between sexes ( $71 \%$ of men, $37 \%$ of women). Therefore, the two sexes probably gave different offers due to different attitudes towards the area, stemming from different knowledge of said area.

The national sample showed significant difference between those with a higher education, and those without one. $29 \%$ of those with a diploma would offer contributions to protect the side branch, while only $13 \%$ of those who do not have a diploma. The ratio of the average WTP sum was four times as much. As we can observe in general trends, higher education and income also had a positive correlation within the sample. Without further analysis, we can not say if the higher WTP resulted from the denser knowledge and social responsibility coming with higher education, or if it is a result of a higher income. An interesting result is how the national sample yielded significant differences between participants with and without children. While nearly two-thirds of the former would pay for the side branch, only one out of eight of the parents said the same. Looking at the average WTP sum, the difference is four times, between households with and without a child. Contrary to this, the fact that a household has a child, or has none held no significance in the Mohács town sample.

\section{Correlation between cognitive variables and the WTP}

As expected, positive willingness to pay was in the strongest correlation with the prior knowledge about the area. In the Mohács town sample, both the basic WTP and the ones following the filter questions yielded significantly higher amounts of positive offers from those who knew the sample area, or visited the side branch before. The ratio with the average offer is twice for the basic WTP, and five times for the valid WTP. The national questionnaire also yielded similar results: those who heard of the case before were more willing to offer contributions, and higher amounts.

Yet another positive effect was if the participant visited the Danube-Drava National Park before, where the Szabadság Island can be found. This group gave an average 3,94 
EUR / household / year in the national sample, while those who never visited the national park would only pay 1,37 EUR. Though the income of those who know the national park is higher in general, the difference is slim, which is why the higher WTP should be attributed to positive attitude, rather than differences in income.

Basically everyone in the Mohács town sample visited the protected Szabadság Island, barely a few kilometres from the city, which is why this variable is not relevant. We also found that the connection with environment protection was positive for both the Mohács town and the national samples, but the correlation was too weak, and non-significant between the offered contribution and the environmental attitude.

We evaluated the correlation between willingness to pay, and direct usage for the Mohács town sample as well. Out of the questions related to TEV (total economic value) elements' importance, only the recreational usage question's answers (on a 1-4 scale) were cross-tabulated with the WTP frequency, and the sum of contributions, which yielded a weak positive correlation in the end.

\section{Comparison between results of the Mohács town and national samples}

In accordance with prior expectations, the contingent valuation's results show that the Szabadság Island area had much more value for the inhabitants of Mohács town, than for those who live in other parts of Hungary. This became apparent in the frequency of positive offers, and the amount of contribution offered as well. The participants of the Mohács town sample gave an offer higher by an average of $85 \%$ for the first question than those living farther. After the filter questions, they were less frequent to change their offers, which means that their WTP value for the side branch was more than 2,5 times as much as the national value (Figure 3).

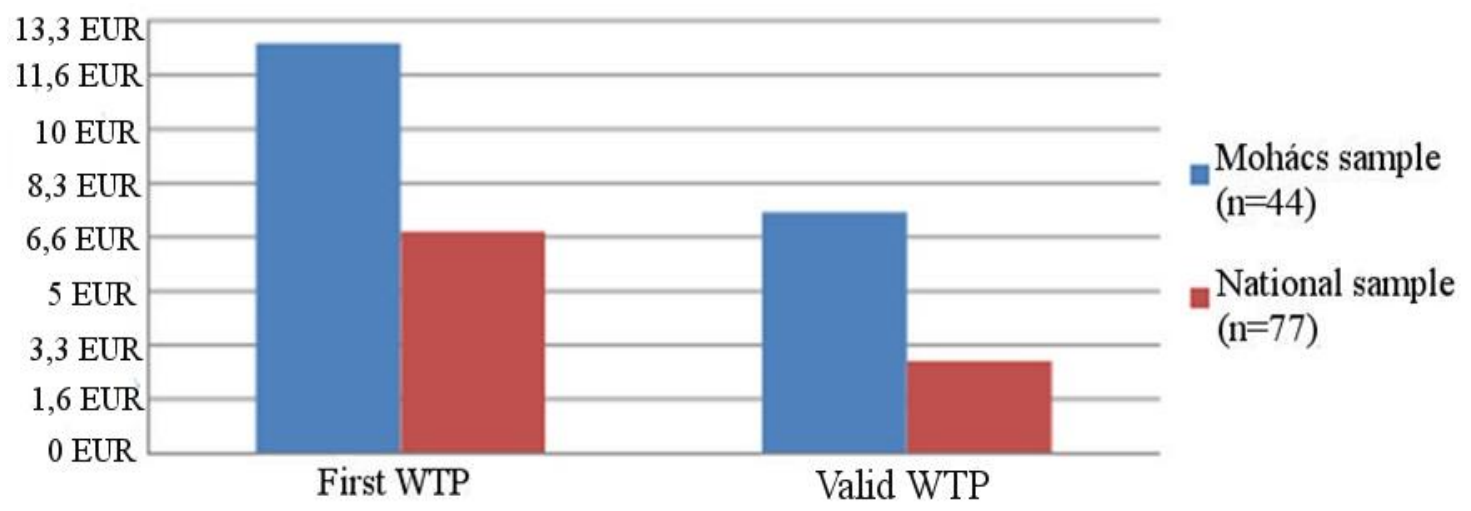

Figure 3. Average willingness to pay for Mohács town and national samples

The closer relationship of the locals to the area's natural values - which also appears in their willingness to pay - clearly aligns with the data from literature (Barton et al., 2011). However, the most important factors in support do not differ: both questionnaires yielded that participants selected the love for nature and the Danube, and conservation for future generations as the most notable factor. Therefore, the CVM method made it possible to evaluate at least partially the values unrelated to usage as well.

The third most notable reason in the national sample was to contribute to a good cause, while in the Mohács town sample, the opportunity for direct usage. Furthermore, every second participant of the Mohács town sample said that they had either partial, or 
complete prior knowledge of the Szabadság Island's history, while the ratio of this in the national sample was merely $12 \%$. This was the factor with a significant effect on willingness to pay, apart from personal connection. The summarised values of the two questionnaires can be seen in Table 9.

Table 9. Cross-referencing WTP and independent variables in the Mohács town and national samples

\begin{tabular}{|c|c|c|c|}
\hline & $\begin{array}{c}\text { Mohács town } \\
\text { sample } \\
(\mathbf{n = 4 4 )}\end{array}$ & $\begin{array}{c}\text { National sample } \\
(\mathbf{n = 7 7 )}\end{array}$ & $\begin{array}{c}\text { National and Mohács } \\
\text { town sample ratios }\end{array}$ \\
\hline Base WTP>0 & $57 \%$ & $44 \%$ & $77 \%$ \\
\hline Valid WTP>0 & $41 \%$ & $26 \%$ & $63 \%$ \\
\hline Avg. base WTP & $12,65 \mathrm{EUR}$ & $6,84 \mathrm{EUR}$ & $54 \%$ \\
\hline Avg. valid WTP & $7,42 \mathrm{EUR}$ & $2,84 \mathrm{EUR}$ & $38 \%$ \\
\hline $\begin{array}{c}\text { Ratio of base and valid } \\
\text { avg. WTP }\end{array}$ & $59 \%$ & $42 \%$ & $71 \%$ \\
\hline Minimum WTP & $3,3 \mathrm{EUR}$ & $1,6 \mathrm{EUR}$ & $50 \%$ \\
\hline Maximum WTP & $120 \mathrm{EUR}$ & $33,3 \mathrm{EUR}$ & $28 \%$ \\
\hline $\begin{array}{c}\text { Avg. income of } \\
\text { households }\end{array}$ & $703,7 \mathrm{EUR}$ & $1047,62 \mathrm{EUR}$ & $149 \%$ \\
\hline Avg. income per capita & $270 \mathrm{EUR}$ & $416,5 \mathrm{EUR}$ & $154 \%$ \\
\hline Prior knowledge & $50 \%$ & $12 \%$ & $24 \%$ \\
\hline
\end{tabular}

\section{Aggregating the willingness to pay}

We aggregated the results of the local and national questionnaires, for both the inhabitants of Mohács town, and those of Hungary. Then, we summarised the two results. During the aggregation, we only included households with at least one earner, and calculated with the value corrected with this. Our resulting, one-year aggregated WTP was further re-calculated for a ten-year period, since the WTP question clearly asked for "contributions annually, for the next ten years". We used a $2 \%$ inflation and a $3 \%$ social discount value for the ten-year present value calculation. Our resulting values can be seen in Table 10, where we can clearly see that the average WTP value of the Mohács town sample is 2,6 times as much as the national value.

Table 10. Aggregated values of the willingness to pay

\begin{tabular}{|c|c|c|c|c|}
\hline & $\begin{array}{c}\text { Average valid } \\
\text { WTP (EUR) }\end{array}$ & $\begin{array}{c}\text { Households } \\
\text { with active } \\
\text { earners (num) }\end{array}$ & $\begin{array}{c}\text { Total WTP } \\
\text { annually (EUR) }\end{array}$ & $\begin{array}{c}\text { 10-year sum on } \\
\text { present value } \\
\text { (EUR) }\end{array}$ \\
\hline Mohács town & 7,42 & 4410 & 32.737 & 265.425 \\
\hline $\begin{array}{c}\text { National (w/o } \\
\text { Mohács town) }\end{array}$ & 2,84 & 2.532 .012 & 7.190 .914 & 58.302 .649 \\
\hline Sum & - & 2.536 .422 & 7.223 .651 & 58.568 .073 \\
\hline
\end{tabular}


Marjainé and associates (2009) recommend three correctional points for the evaluation of rehabilitation of water bodies, with value transfer. These are the importance of the water body in question, the income of the inhabitants, and the direct usage. The income can be found in official databases, which means that it is useful not only to modify the results for value transfer with, but during primary analyses as well, as it can be used to rebalance non-representative sampling. If the participants of the sample have a much higher income than average, the average WTP can be corrected with the difference in income. The income and WTP were only in significant correlation in the national sample, therefore, the correction was only applied to the national value. The income per capita calculated from the HCSO database and the income per capita for the sample showed difference, hence the average WTP was modified with a regression coefficient. The modified aggregated results can be seen in Table 11 .

Table 11. Aggregated values of willingness to pay, modified by income

\begin{tabular}{|c|c|c|c|c|}
\hline & $\begin{array}{c}\text { Average valid } \\
\text { WTP (EUR) } \\
\text { modified with } \\
\text { income }\end{array}$ & $\begin{array}{c}\text { Households } \\
\text { with active } \\
\text { earners (num) }\end{array}$ & $\begin{array}{c}\text { Total WTP } \\
\text { annually (EUR) }\end{array}$ & $\begin{array}{c}\text { 10-year sum on } \\
\text { present value } \\
\text { (EUR) }\end{array}$ \\
\hline Mohács town & 7,42 & 4410 & 32.737 & 265.425 \\
\hline $\begin{array}{c}\text { National (w/o } \\
\text { Mohács town) }\end{array}$ & 1,99 & 2.532 .012 & 5.038 .704 & 40.852 .912 \\
\hline Sum & - & 2.536 .422 & 5.071 .441 & 41.118 .337 \\
\hline
\end{tabular}

If we look at willingness to pay as an interval, the value modified with income can be considered as the lower border value, and the original value as the upper border value. This means a 5.038.704 EUR - 5.071.441 EUR annual welfare increase for the entire Hungarian nation if the Szabadság Island side branch's rehabilitated state is sustained. The present value of this calculated for ten years is 40.852.912 - 41.118.337 EUR. Our contingent valuation's results suggest that the rehabilitated state of the side branch is worth at least this much to the entire society.

\section{Cross-referencing local and national values with results of other research}

We chose Marjainé's (2011) similar research as the reference to compare our local WTP values with, where she researched the willingness to pay of inhabitants in smaller areas with extreme water conditions related to local water management. Figure 4 shows the cross-referencing of these three areas' average willingness to pay, and our own research results. 


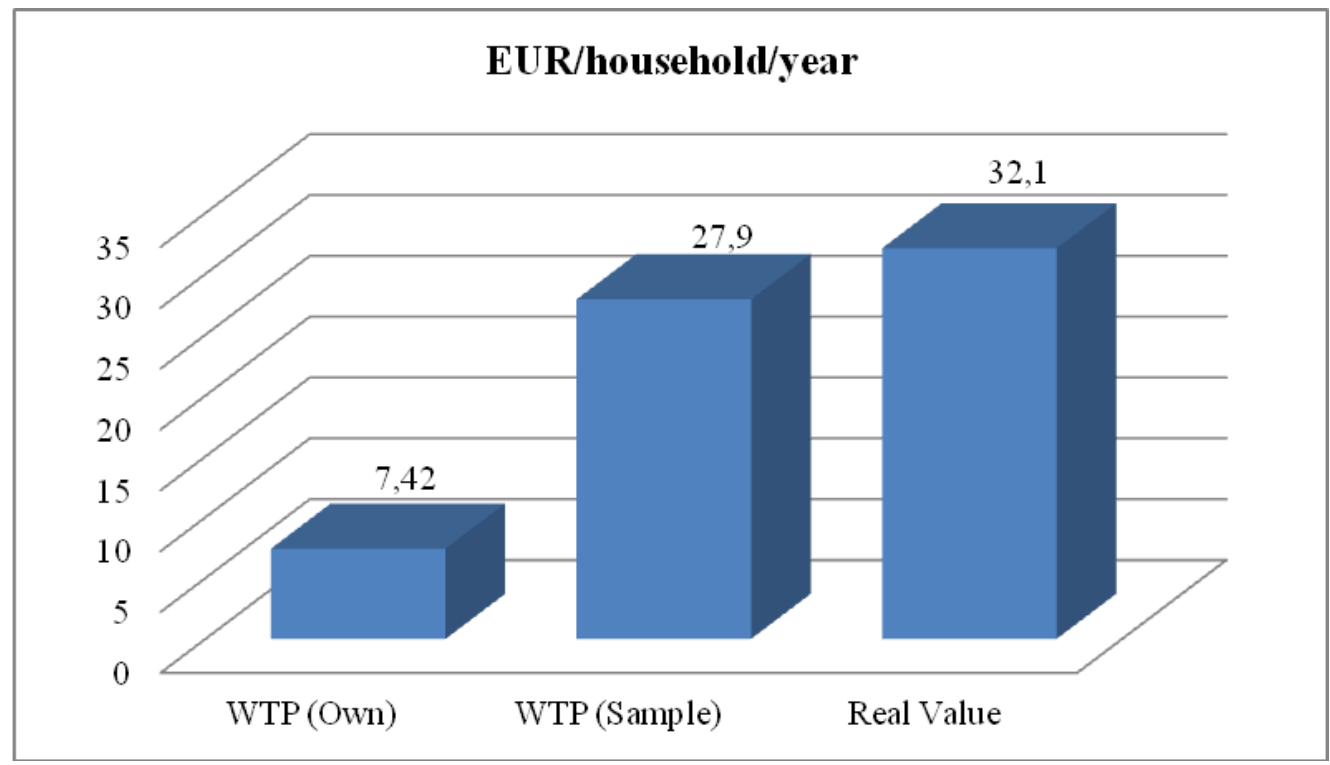

Figure 4. Evaluation of the local results

Source: Self-made, based on Marjainé (2011) and our own research

In the first column of the illustration [WTP (Own)], we can see that the inhabitants of Mohács town significantly undervalued the project compared to other local initiatives [WTP (sample)], where the locals would have paid higher contributions to make the initiative a success. The second column shows the willingness to pay of the three areas which were used as a reference basis. Finally, the third column shows our calculations of the actual costs of the side branch restoration project, which ran from 2009 to 2013, on future value. This shows what is the amount the households of Mohács town would've had to pay for 10 years, in order to cover all costs. If we also take this into consideration, we can say that the natural resources are quite underrated in our area of analysis compared to other Hungarian examples, and to the amounts spent.

To evaluate the results of the national questionnaire, we used the 2009 study "Economic Valuation of Environmental and Resource Costs and Benefits in the Water Framework Directive: Technical Guidelines for Practitioners" by Aquamoney, which measured the attitudes of the member states' inhabitants of the European nations towards water management and environment protection projects. The methodology of the research was based on the intent to unearth what amount of money the countries' inhabitants are willing to pay for the national water quality to be raised to 'ecologically good'. Their research resulted in that a Hungarian household's annual willingness to pay for this is 50 EUR each (Brouwer et al., 2009). If we include that Hungary's various streams are $52.335 \mathrm{~km}$ long in total, we can see that the Hungarian society is willing to pay 0,0009 EUR for the protection and conservation of a $\mathrm{km}$ of stream. During our analysis, we saw how the idea that locals value their own environment more than those living farther away holds true. However, in light of this data, we can see that the project realised in the Mohács town area (3,5 km long) was significantly overrated, since the average 1,99 EUR contribution offer of households amounts to 0,56 EUR for each $\mathrm{km}$ (Figure 5). 


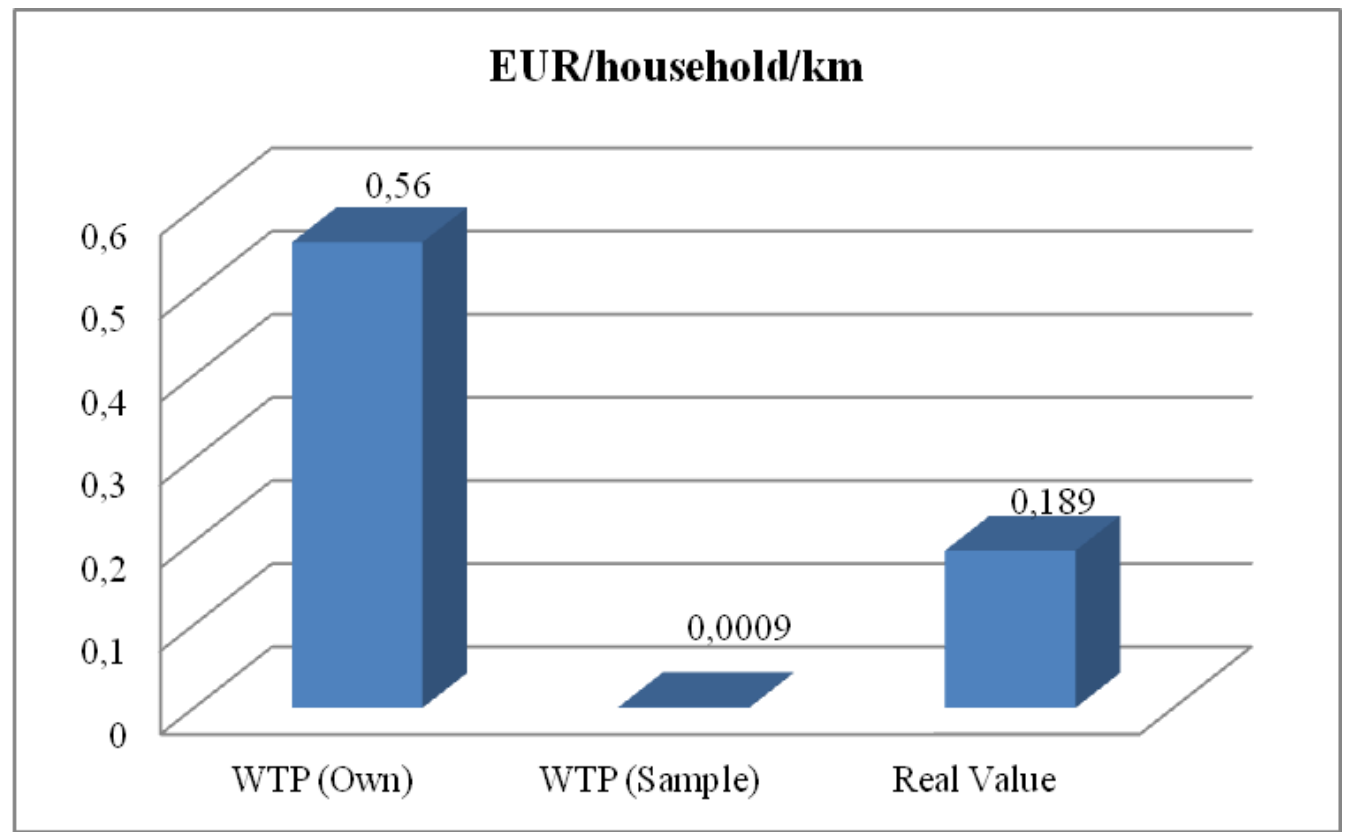

Figure 5. Evaluation of the national results

Source: Self-made, based on Brouwer et al. (2009) and our own research

The illustration shows out own national results with the WTP (Own) label, while the WTP (Sample) shows Aquamoney's project reference. Furthermore, based on the actual costs of the project, we once again looked at what Hungarian households would've had to be willing to pay to finance the initiative from their contributions. We have to state that in this case, we are not talking about a 10 year contribution process, but a single amount. And based on this, we can see that the national contributions observed during the course of our evaluation were enough to cover the project's actualisation multiple times.

\section{Discussion}

At this point, our research yielded an interesting result, since we were able to see our hypothesis hold true in the first round, meaning the locals were much more generous with the monetary evaluation of the rehabilitation, than those who lived farther away. The overview of literature, and the comparison with actual costs however showed that while the project proved underrated locally, the national willingness to pay would have generously financed the actualisation process with excess.

The research of the sample area proves that monetary environment evaluation methods are applicable to prove how valuable related people consider a given natural area. Based on the research, it became apparent that the locals may interpret their known natural resource up to twice and a half as valuable as any other unknown areas. We can assess a welfare increase for the entire society stemming from natural resource conservation or rehabilitation, which is in line with the value definition of the neoclassic economics. However, based on the literature, we should separately handle two of the many limits of the evaluation methods. One is that nature's value may only be expressed in monetary terms when in contact with humanity, as a human's perceived usefulness is something that can be translated to figures. Nature's intrinsic values, unrelated to human society, its own value for itself stays 
unreachable within the boundaries of economics. The other is that values estimated through costs or hypothetic markets usually don't offer enough of a basis for correcting disadvantages of the lack of market, which is shown by different WTP values calculated for similar areas. Furthermore, to properly compensate for the ecosystem's services in a market framework and thereby rearranging negative development tendencies, we don't have well-working structures in the European policies for now.

However, based on our conducted analyses, we can say that:

- WTP methods and result elements should be corrected with details, which also represent actualised costs in similar projects,

- when talking about the results, we have to stress that the number of answers, in other words, the number of the sample is a significant factor of representativeness, but references to the driven process of the analysis, in other words, the actual, experiencebased data also have to have proper weight during questioning,

- WTP answers also clearly show how actual costs and related social groups' environmental requirements may show great differences, which may question the validity of WTP.

According to the analyses, we can state that it is advised to add unit definitions to related costs during WTP questionnaires, because the results may contain significant errors otherwise, and therefore serve as a basis for wrong assumptions. In order to make adaptation possible, getting to know the mechanisms already working in market economies overseas based on paying for the ecosystem services is advised. The contingent valuation conducted for both the local and national sample clearly shows that people consider things more valuable if they know them. Therefore, one key to conserving natural capital is to develop knowledge related to it, and to spread knowledge to decision-makers and laymen about it. If decision-makers and citizens/consumers would know the mechanisms and resulting benefits of healthy natural systems, we'd need a shorter step to integrate this information into daily economic and political decisions' operating logic. This is why evaluating nature, and introducing its resources should get a bigger share of general coverage.

\section{REFERENCES}

[1] Arrow, K., Solow, R., Portney, P., Leamer, E., Radner, R., Schuman, H. (1993): Report of the NOAA Panel on Contingent Valuation. - US Federal Register 58 (10): 4602-4614.

[2] Barton, D. N., Lindhjen, H., NINA, Magnussen, K., Sweco, N., Holen, S., NIVA (2011): Valuation of Ecosystem Services from Nordic Watersheds. Nordic Council of Ministers, Copenhagen. doi: 10.6027/TN2012-506

[3] Bateman, I.J., Cole, M., Cooper, P., Georgiou, S., Hadley, D., Poe, G.L. (2004): On visible choice sets and scope sensitivity. - Journal of Environmental Economics and Management 47: 71-93. doi: 10.1016/S0095-0696(03)00057-3

[4] Bateman, I.J., Day, B.H., Georgiou, S. and Lake, I. (2006): The aggregation of environmental benefit values: Welfare measures, distance decay and total WTP. Ecological Economics 60 (2): 450-460. doi: 10.1016/j.ecolecon.2006.04.003

[5] Boddington, M.A.B. (1993): Financial and Economic Measurement of Environmental Factors. - Journal of the Institute of Water and Environmental Management 7: 125-133.

[6] Brouwer, R., Barton, D., Bateman, I., Brander, L., Georgiou, S., Martín-Ortega, J., Navrud, S., Pulido-Velazquez, M., Schaafsma, M., Wagtendonk, A. (2009): Economic Valuation of Environmental and Resource Costs and Benefits in the Water Framework 
Directive: Technical Guidelines for Practitioners. - Institute for Environmental Studies, VU University Amsterdam, the Netherlands.

[7] Boros, T. (2004): Két új ökológiai fogalom: a „természeti töke” és a „környezeti fenntarthatóság" értelmezése és alkalmazása gyakorlati problémákra. - Múszaki információ. Környezetvédelem 9-10: 3-23.

[8] Brand, F.S. (2009): Critical natural capital revisited: ecological resilience and sustainable development. - Ecological Economics 68: 605-612. doi: doi:10.1016/j.ecolecon.2008.09.013

[9] Costanza, R., Daly, H.E. (1992): Natural capital and sustainable development. Conservation Biology 6: 37-46.

[10] Koetse, M.J., Brouwer, R. (2015): Reference Dependence Effects on WTA and WTP Value Functions and Their Disparity. - Environmental and Resource Economics 61: 1-23. doi: 10.1007/s10640-015-9920-2.

[11] MA (2005): Millennium Ecosystem Assessment, 2005. Ecosystems and Human Wellbeing: Synthesis. - Island Press, Washington.

[12] Marjainé Sz.Zs. (2005): A természetvédelemben alkalmazható közgazdasági értékelési módszerek / Economic evaluation methods in the nature protection practice - Ministry of Environmental and Water Management, Special Edition, Budapest, 2005

[13] Marjainé Sz.Zs. (2011): Az ökoszisztéma-szolgáltatások közgazdaság-tudományi megközelítése / Economic aspects of ecosystem service and management. - Magyar Tudomány 172 (7): 788-795.

[14] Nijkamp P., Vindigni G., Nunes, P. A. L. D. (2008): Economic valuation of biodiversity: A comparative study. - Ecological Economics 67: 217-231. doi: 10.1016/j.ecolecon.2008.03.003

[15] Norgaard, R.B. (2010): Ökoszisztéma szolgáltatások - Hogyan vált egy szemléletes metafora a lényeg elhomályosítójává? - Kovász 15 (1-4): 61-92.

[16] Koopman, J.L., Kuik, O.J., Tol, R.S.J. Brouwer, R. (2015): Water scarcity from climate change and adaptation response in an international river basin context. - Climate Change Economics 6 (1): 1-22. doi: 10.1142/S2010007815500049

[17] Pavan, Sukhdev (2008) The economics of ecosystems and biodiversity. European Communities, Banson Production, Cambridge UK, 2008 p. 33 web: http://ec.europa.eu/environment/nature/biodiversity/economics/pdf/teeb_report.pdf

[18] Pearce, D., Moran, D. (1994): The Economic Value of Biodiversity. - IUCN, Earthscan Publications Ltd., London.

[19] TEEB Foundations (2010): The Economics of Ecosystems and Biodiversity Ecological and Economic Foundations. - Earthscan, London and Washington.

[20] Turner, R. K., Pearce, D., Bateman, I. (1994): Environmental Economics: An elementary introduction. - John Hopkins University Press, Baltimore.

[21] Van den Bergh, J.C.J.M., Botzen, W.J.W. (2015): Monetary valuation of the social cost of greenhouse gas emissions. - Ecological Economics 114: 33-46. doi: 10.1016/j.ecolecon.2015.03.015

[22] Van Zanten, B.T., Verburg, P.H., Koetse M.J., Van Beukering, P.J.H. (2014): Preferences for European Agrarian Landscapes: A Meta-Analysis of Case Studies. - Landscape and Urban Planning 132: 89-101. doi: 10.1016/j.landurbplan.2014.08.012

[23] Vatn, A., Bromley, D.V. (1994): Choices without Prices without Apologies. - Journal of Environmental Economics and Management 26 (2): 129-148. doi: 10.1006/jeem.1994.1008 